\title{
Effect of A Non-Steroidal Aromatase Inhibitor on Ovarian Function and Synchronicity of Estrus in Ewes at Subtropics
}

\author{
Abdel Dayem M. A. ${ }^{1}$, Hassan M. ${ }^{1}$, Fadel M. ${ }^{2}$, Senosy W. ${ }^{1 *}$ \\ ${ }^{1}$ Theriogenology Department, Faculty of Veterinary Medicine, New Valley University, Al kharga,72511,Egypt. \\ ${ }^{2}$ Diagnostic ultrasound unit, Animal reproduction institute, Giza, Agricultural Research Center (ARC), Egypt. \\ "Corresponding Author, Waleed Senosy, E-mail: senosy_76@yahoo.com
}

\begin{abstract}
Effects of non-steroidal aromatase inhibitor letrozole on ovarian function in ewe were investigated through testing the hypothesis that letrozole will arrest the growth of dominant follicles, resulting in the emergence of a new follicular wave at a predictable post-treatment interval. Treatment ewes $(n=10)$ were treated using an intravaginal sponge (regardless of the stage of estrus) containing $7.5 \mathrm{mg}$ letrozole for five days followed by prostaglandin injection. The control group ( $\mathrm{n}$ $=10$ ) was treated with gonadotropin prostaglandin gonadotropin (GPG) protocol for ovarian synchronization. Ovarian structures were daily monitored with trans rectal ultrasonography concomitant with blood sampling. Commercial enzyme-linked immunosorbent assay Kits assigned steroid concentration of estradiol, testosterone and progesterone. Some biochemical parameters including blood glucose, total proteins, lipid profiles were measured as a preliminary screening for the effect of applied letrozole treatment on ewes general health condition. Treatment with letrozole decreased serum concentrations of estradiol during sponge insert in the vagina while its concentration increased following removal correlated with the number of ovulatory follicles. On the other hand, the concentration of Progesterone increased correlated with increased number and diameter of corpora lutea resulting from increased diameter and number of ovulatory follicles. The onset of estrus was about $54.00 \pm 0.40 \mathrm{hrs}$. After sponge removal and continued for $25.17 \pm 0.24 \mathrm{hrs}$. Ovulation was synchronous and occurred at $78.70 \pm 0.21 \mathrm{hrs}$ after sponge removal. There was no effect of letrozole treatment on measured metabolic parameters. We concluded that letrozole proved to have potential as a non-steroidal treatment for controlling ovarian function and onset of estrus in the ewe.
\end{abstract}

Keywords: Aromatase inhibitor, Letrozole, Ewe, Synchronization, Estradiol.

J. Appl. Vet. Sci., 5(4): 1 - 9 .

\section{Original Article: \\ HTTPS://DX.DOI.ORG/10.21608/JAVS.2020. $\underline{117991}$}

Received:14 July, 2020.

Accepted :20 Aug., 2020.

Published in October, 2020.

This is an open access article under the term of the Creative Commons Attribution 4.0 (CC-BY) International License . To view a copy of this license, visit http://creativecommons.org/licenses/by/4.0/

\section{INTRODUCTION}

Sheep production is considered a suitable candidate for increasing lamb and meat production covering daily increasing human demands with a profitable role in solving local shortage in animal proteins (LENG, 1990), with the lower cost of production when compared with that of cattle (Martin, 2016).especially when intensive managemental practices such as application of estrus synchronization were adopted (Kulaksiz and Ucar, 2013, Gootwine, 2017).
Increasing concern regarding the toxicity of hormonal preparations used to promote growth rates in cattle and the hazard of the potential carcinogenicity of steroid hormone residues in meat or milk concluded to prohibiting the use of estrogens and other steroid hormones as growth promoters in animals designated for human consumption in all states of the European Union as of 1 January 1989(Andersson, and Skakkebaek, 1999; Daxenberger et al., 2001 and Official Journal of the European Union, 2003). Replacement true solutions are rapidly required to compensate for the future absence of steroids. 
The aromatase enzyme, P450arom, belongs to the super-family of $\mathrm{P} 450$ proteins which includes more than 480 members divided in74 different families. P450arom is a unique member of family 19 (Simpson et al., 2002) which is located in the endoplasmic reticulum of mammalian cells in which the CYP19 gene is expressed, such as adipose tissue, brain, adrenal glands, gonads, liver and placenta (Vanselow et al.,2001), P450arom contains a heme group in its structure and is functionally associated with another member of P450 cytochrome family, NADPH reductase, which acts as a donor of reductive equivalents (Simpson et al., 2002). It is responsible for catalyzing the final, rate-limiting step in the production of estrogens (estrone and estradiol) from C19 substrate (androstenedione and testosterone). Inhibitors of aromatase bind to the heme group in the P450arom, (occupying part of the active binding site of the enzyme) and reversibly interfere with enzyme activity. Examples of these Type II estrogen synthetase-specific inhibitors are letrozole, anastrozole, and fradozole (Goss and Strasser, 2001).

Estradiol hormone suppresses gonadotropin release through negative feedback effects on the hypothalamo-pituitary axis. Theoretically when circulating estradiol is removed by means of aromatase inhibitors, the suppressive effects of estradiol will be removed permitting a new surge of $\mathrm{FSH}$, which could in-turn induce the recruitment of a new wave of follicular development (Requena et al., 2008) and this effect is already obtained in our experiment after removal of sponges

At the current time clinical use of Aromatase inhibitors in human reproductive medicine is focused on inducing normal folliculogenesis in women with polycystic ovarian syndrome, in addition to ovarian stimulation with or without exogenous gonadotropins prior to intrauterine insemination, oocyte collection and IVF, and in women desiring fertility preservation throughout cancer therapies (Verpoest.et al., 2006).

According to the results obtained from the bovine model that was used to determine the effects on ovarian function, it was found that letrozole treatment extended the lifespan of the dominant follicle which in role delayed the emergence of the next follicular wave and/or ovulation(Yapura et al., 2017). Beside its luteotrophic effects which expressed in the form of larger CL and increased concentrations of circulating progesterone in letrozole-treated animals. The results obtained from initial studies in cattle inspired an impetus for the development of aromatase inhibitorbased synchronization protocol in cattle(Yapura et al., 2017).
That's what triggered our ambitions in the development of letrozole dependent synchronization protocol in sheep based on available data from researches in cattle and its effect on humans besides our research trials. Therefore, in the present study, letrozole synchronizing efficacy was investigated in farafra ewes when compared to GPG protocol and its effect on ovarian activity.

\section{MATERIALS AND METHODS}

\section{Animals and experimental design}

The study was conducted during the breeding season (September-October) at the veterinary teaching hospital in faculty of veterinary medicine, New Valley University, Al Kharga city (latitude $25^{\circ} 30^{\prime} 53^{\prime \prime} \mathrm{N}-30^{\circ}$ $35^{\prime} 47^{\prime \prime}$ E). Twenty cyclic non-lactating Farafra ewes ranging from 3 to 5 years in age and weighing 35-40 $\mathrm{kg} / \mathrm{BW}$ were assigned for the study, Ewes were clinically healthy (rectal temperature, pulse rate, respiratory rate and color of mucus membranes were normal). Ewes were kept indoors with outdoor access with concrete floor. Balanced ration and good quality hay were provided ad labitum in addition to concentrate mixture. The animals were provided daily at the level of $1 / 2 \mathrm{~kg}$ per head with mineral mixture were added.

Ewes were randomly divided into two equal groups each containing ten ewes; the first group were letrozole Group which received Vaginal sponge containing $7.5 \mathrm{mg}$ letrozole for five days then $250 \mu \mathrm{g}$ of Prostaglandin $\mathrm{F}_{2 \alpha}$ were given intramuscularly at oncet of sponge removal, while the other group named GPG group and treated with GPG protocol as in Fig. (1).

\section{Preparation of sponges}

Vaginal sponges $(2 \mathrm{~cm}$ width, $2 \mathrm{~cm}$ thickness, $3 \mathrm{~cm}$ length piece of sponge provided with $15 \mathrm{~cm}$ silk) sterilized in an autoclave, left to dry and stored in sterilized closed corkscrewed glass bottle till used. Each sponge was loaded by $7.5 \mathrm{mg}$ letrozole powder (Femara ${ }^{\circledR}$ Tablets 2.5 mg-Novartis Pharmaceuticals corporation) just before its introduction into the vagina using suitable sterilized $2 \mathrm{~cm}$ diameter glass tube opened from both sides guided by a metal probe to push loaded sponge through glass tube till settle inside the vagina of the ewe. Both glass tube and metal rod were gently removed and silk was cut at $1 \mathrm{~cm}$ below the level of the vulva, to avoid accidental sponge withdrawal which is kept there for five days. During sponge removal, treatment ewes were given an intramuscular injection of $250 \mu \mathrm{g}$ of cloprostenol (Estrumate; Mallinckrodt Vet $\mathrm{GmbH}$, Friesoythe, Germany). Ewes were observed and examined for estrus signs through the introduction of ram and observing whether ewes refuse ram or searching for its accompany and stand to be mounted. 


\section{Monitoring of follicular development}

Daily ultrasound examination by using an ultrasound scanner (ECM80, Exago, France), equipped with a 5-10 MHz endorectal linear probe attached to an Extender.

The examination was carried out in lateral recumbency. The fatty tail was raised, after the evacuation of the rectum with lubricated, gloved fingers an ultrasound lubricant gel was placed into probe then it is introduced into the rectum, The urinary bladder was used as a guide to find the uterine horn. The probe was rotated laterally $90^{\circ}$ clockwise and $180^{\circ}$ anticlockwise to scan the ovaries and explore all parts of genitalia as stated by (Ginther, 1984).

\section{Biochemical and hormonal analysis}

Blood samples were collected by (according to figure.1) Jugular vein puncture into $5 \mathrm{ml}$ plain vacuum tubes (vacutainer system). For letrozole group sampling was once daily from the onset of sponge insertion and along period when sponge in the vagina, six hours after sponge were removed then twice daily until ovulation has occurred then sampling were taken once daily, while for GPG group, sampling was every other day along the time of the experiment. Collected samples (Fig:1) were centrifuged at $2500 \mathrm{rpm}$ for 15 minutes and serum was separated and placed into 1.5 $\mathrm{ml}$ eppendorf tubes, labelled and stored frozen at -20 ${ }^{\circ} \mathrm{C}$ till assayed.

Blood glucose was determined using GODPAP enzymatic colourimetric method (Tietz, 1995). Total protein were determined using colorimetric method (Biuret reagent;Tietz, 1995). Determination of triglycerides was carried out using GPO-PAP enzymatic colorimetric method (Tietz, 1995). Total cholesterol was measured by using CHOD-PAPenzymatic colorimetric method (Tietz, 1995). Highdensity lipoproteins were determined using the precipitation method. Low-density lipoproteins were Calculated according to the following (LDL=cholesterol-(HDL+Triglycerides/5).

Serum concentration of estradiol and progesterone was determined by commercial ELISA kits (Precheckbio, Inc. U.S.A.). Testosterone was determined using a commercial ELISA Kits (BioCheck, Inc. CA94404, Foster City, USA) for the quantitative determination of estradiol in serum or plasma (Tietz, 1995). Based on the concept that aromatase activity is positively correlated with estrogen concentration and estrogen testosterone ratio According to Cason and Ladly Statement (Tsonis and Carson, 1984), Aromatase activity was predicted through concentrations of estradiol and estrogen testosterone ratio.

\section{Statistical analysis}

Statistical analysis of the data obtained in the study was performed by using the Microsoft Excel computer programs (2010), method of analysis. Significant differences among means were analyzed by T-Test.

\section{RESULTS}

\section{Ultrasonic findings of the ovaries}

The number of medium sized follicles before ovulation was significantly averaged $2.85 \pm 0.34$ and $2.15 \pm 0.30$ for letrozole and GPG groups, respectively (Fig. 2A). Moreover, number of large sized follicles did not differ between letrozole group $(0.80 \pm 0.21)$ and GPG Group (Fig. 2B). Interestingly, number of ovulatory follicles were higher $(\mathrm{P}<0.05)$ in letrozole group $(3.67 \pm 0.88)$ when compared to GPG Group $(1.00 \pm 0.58)$; table 1 ). In Fig. 3, diameter of ovulatory follicles before ovulation were larger $(\mathrm{P}<0.05)$ in letrozole group $(6.25 \pm 0.01 \mathrm{~mm})$ than that of GPG group (5.90 $\pm 0.01 \mathrm{~mm})$ plate $(1)$.

Table 1: Reproductive parameters and steriod cocentration in letrozole $(n=10)$ and GPG $(n=10)$ ewes.

\begin{tabular}{|c|c|c|}
\hline Item & $\begin{array}{l}\text { Letrozole } \\
\text { group }(n=10)\end{array}$ & $\begin{array}{l}\text { GPG group } \\
(\mathrm{n}=10)\end{array}$ \\
\hline $\begin{array}{l}\text { Onset of estrus after } \\
\text { sponge removal (hrs) }\end{array}$ & $54.00 \pm 0.40^{\mathrm{a}}$ & $72.64 \pm 1.34^{\mathrm{b}}$ \\
\hline Estrus duration (hrs) & $25.17 \pm 0.24^{\mathrm{a}}$ & $46.52 \pm 1.70^{\mathrm{b}}$ \\
\hline $\begin{array}{l}\text { Ovulation time after } \\
\text { sponge removal (hrs) }\end{array}$ & $78.70 \pm 0.21^{\mathrm{a}}$ & $119.16 \pm 2.30^{\mathrm{a}}$ \\
\hline $\begin{array}{c}\text { Estradiol } \\
\text { concentration } \\
(\mathrm{pg} / \mathrm{ml}) \text { During } \\
\text { Estrus } \\
\end{array}$ & $85.55 \pm 4.70^{\mathrm{a}}$ & $27.60 \pm 1.60^{\mathrm{b}}$ \\
\hline $\begin{array}{l}\text { Number of ovulatory } \\
\text { follicles }\end{array}$ & $3.67 \pm 0.88^{\mathrm{a}}$ & $1.00 \pm 0.58^{b}$ \\
\hline $\begin{array}{c}\text { Number of corpora } \\
\text { lutea (CL) after } \\
\text { ovulation }\end{array}$ & $3.20 \pm 0.39^{\mathrm{a}}$ & $1.90 \pm 0.28^{\mathrm{b}}$ \\
\hline $\begin{array}{c}\text { Progesterone } \\
\text { concentration } \\
\text { (ng/ml) } 3 \text { days post } \\
\text { ovulaion } \\
\end{array}$ & $5.73 \pm 2.80^{\mathrm{a}}$ & $4.52 \pm 0.12^{b}$ \\
\hline $\begin{array}{l}\text { Diameter }(\mathrm{mm}) \text { of } \\
\text { CL } 4 \text { days after } \\
\text { ovulation }\end{array}$ & $6.63 \pm 0.07^{\mathrm{a}}$ & $5.33 \pm 0.18^{b}$ \\
\hline
\end{tabular}

Values with different superscripts in the same row are significantly different at $\mathrm{p}<0.05$. 


\section{Effect of A Non-Steroidal Aromatase Inhibitor on Ovarian Function}

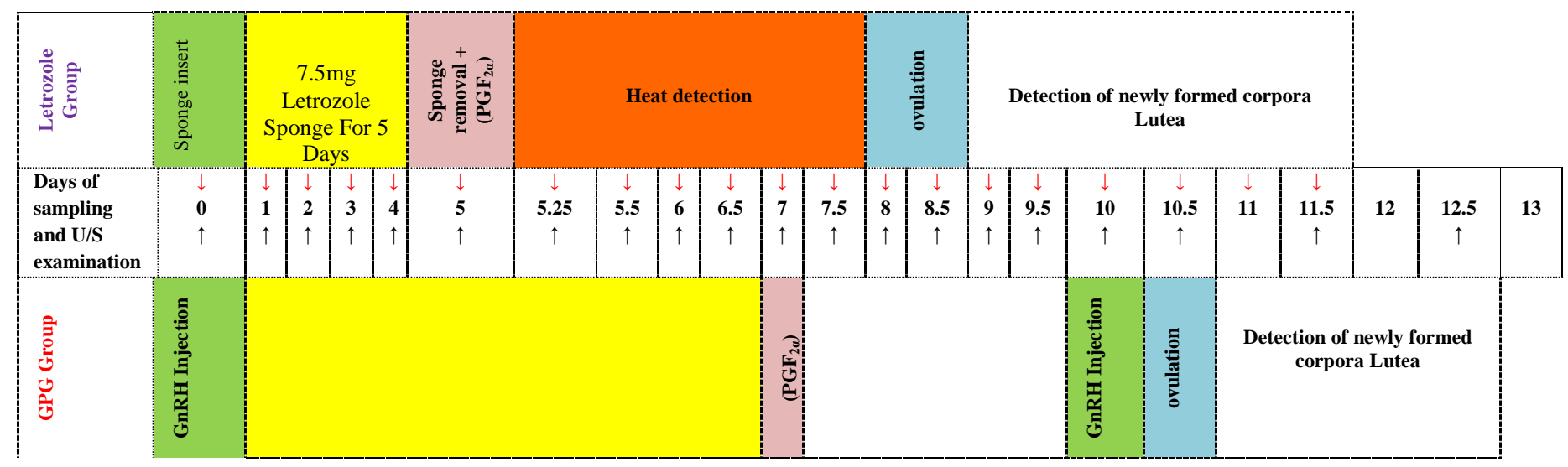

Fig.1: Summery of protocol, time of blood sampling and ultrasound examination for Both Letrozole and GPG Groups.

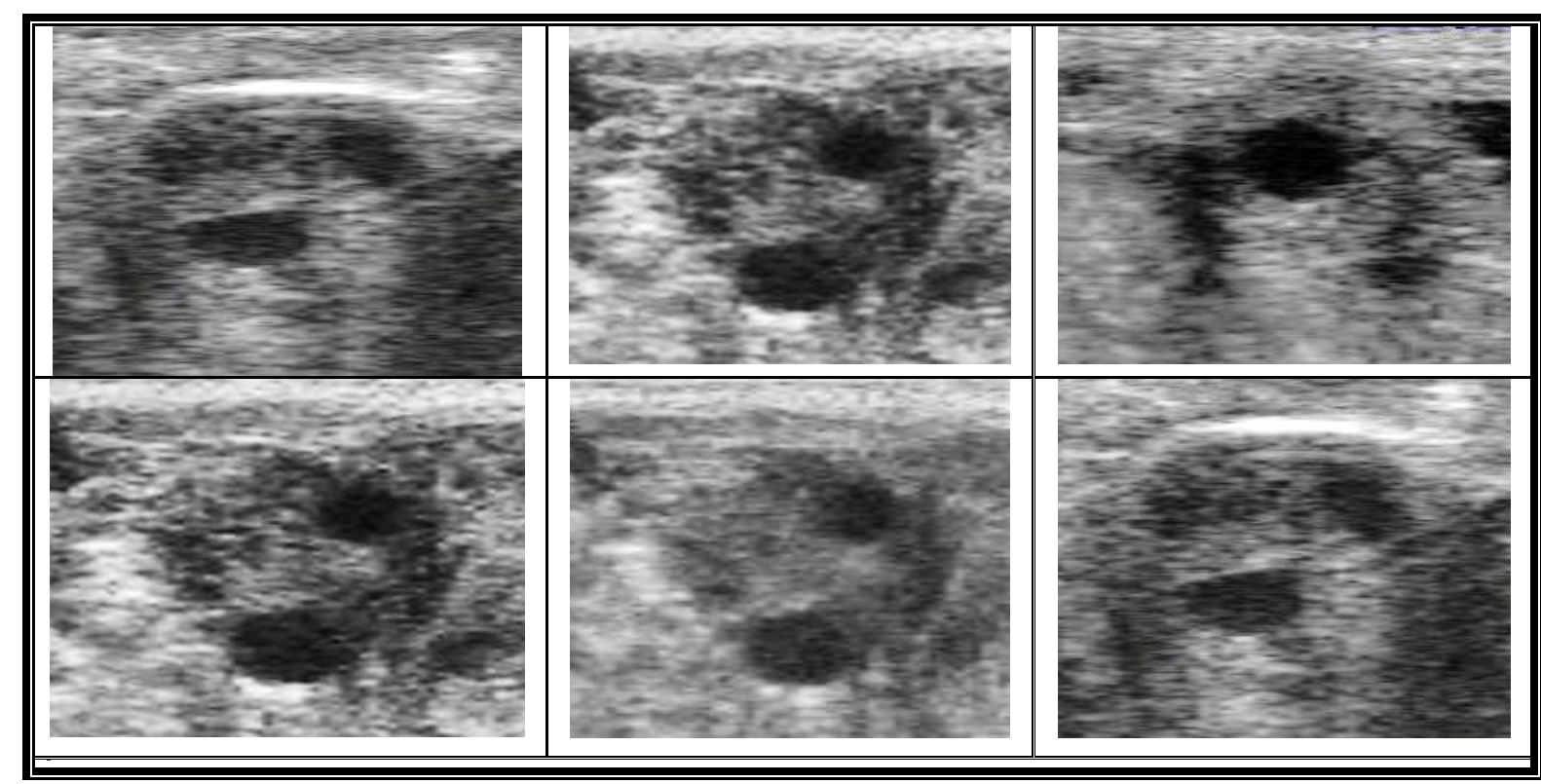

Plate 1: Ultrasonic images were showing preovulatory follicles for letrozole group.
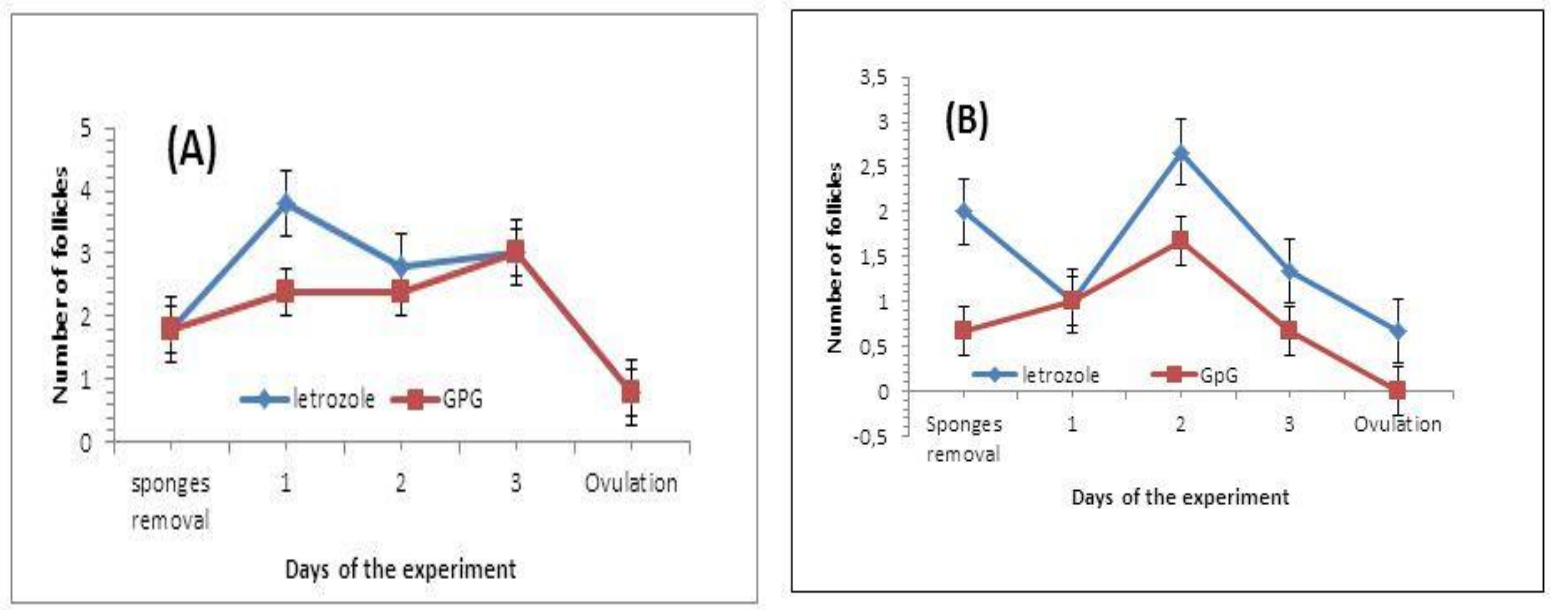

Fig. 2: Number of medium sized follicles (A), Large sized follicles (B). In ewes that treated by aromatase inhibitor (Letrozole Group), And ewes that treated by ovisynch protocol(GPG Group) before ovulation . 
Abdel Dayem M. A.et al.....

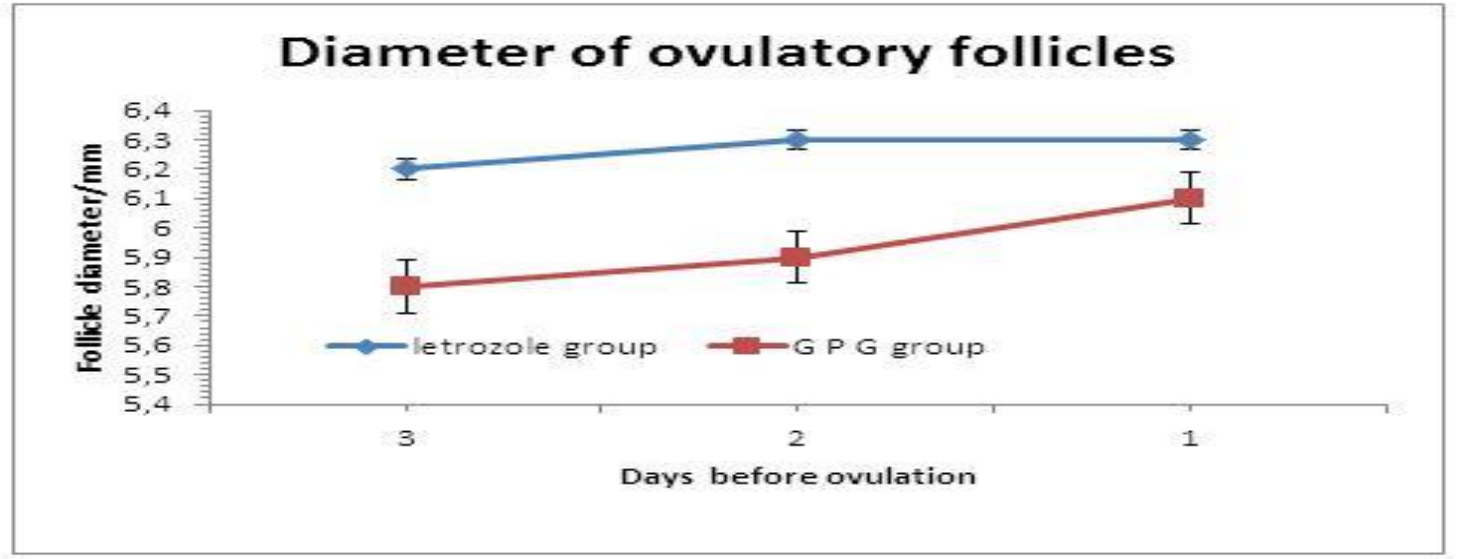

Fig. 3: Diameter of ovulatory follicles along the pre ovulatory period (Mean \pm SEM) in Letrozole $(\mathrm{n}=10)$ and GPG ewes $(\mathrm{n}=10)$ during the study period.

Number of copora lutea post-ovulation were higher $(\mathrm{P}<0.05)$ in letrozole group $(3.20+0.39)$ than that of GPG group $(1.9+0.28)$ throughout the period of the study (Table 1). In Fig 4, CL diameter (mm) after ovulation averaged from( $6.63 \pm 0.07)$. Moreover, diameter of newly formed corpus luteum between letrozole group and GPG group $(5.33 \pm 0.18)$ differed significantly during the period of the study

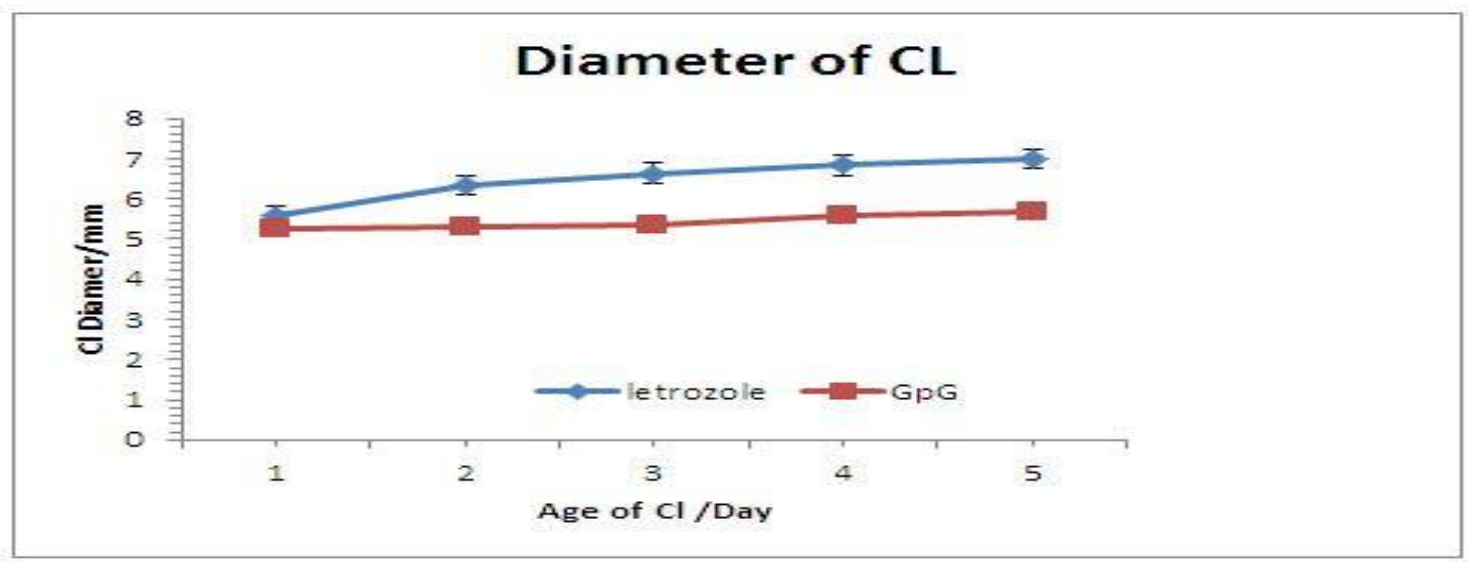

Fig.4: Diameter of CL after ovulation (Mean \pm SEM) in Letrozole $(n=10)$ and GPG ewes $(n=10)$ during the study period.

\section{Steroid concentration}

In letrozole group, serum concentration of estradiol ( $\mathrm{pg} / \mathrm{ml})$ was increased 24 hours post treatment then it continued to decrease for five days till sponges were removed, then concentration of estradiol begin to raise again in association to synchronous follicular recruitment and selection then its second decrease were just before ovulation (Fig. 5).

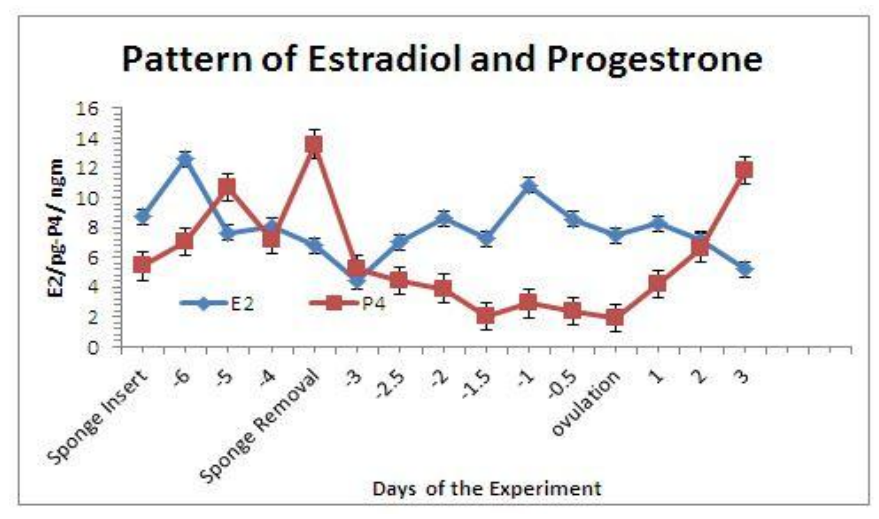

Fig.5: Pattern of estradiol and progestrone (Mean \pm SEM) in Letrozole $(n=10)$ during the study period.

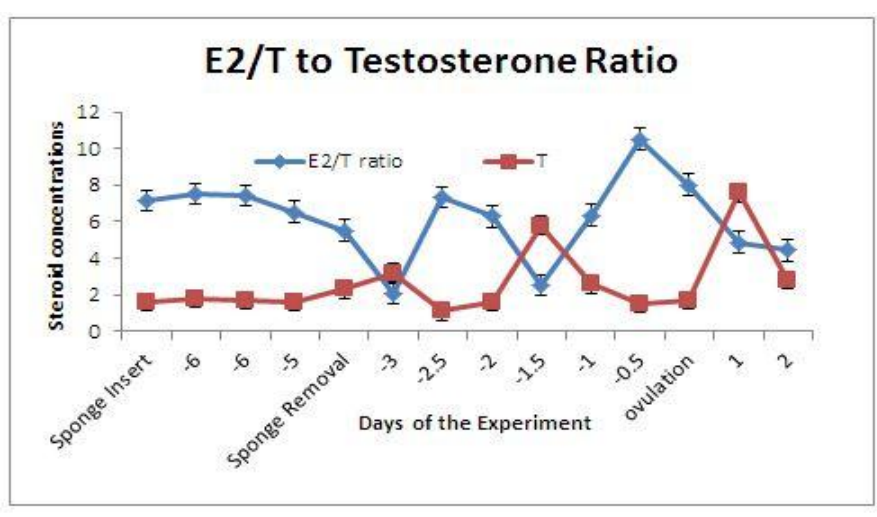

Fig. 6 : Estradiol testosterone(E2/T) to testosterone Ratio $($ Mean \pm SEM) in Letrozole $(n=10)$ and GPG ewes $(n=10)$ during the study period. 
Serum concentration of progesterone $(\mathrm{ng} / \mathrm{ml})$ was slightly increased throughout the period in which sponges were kept on vagina then decreased post removal of sponges and injection of luteolytic agent. Serum concentration of testosterone $(\mathrm{ng} / \mathrm{ml})$ were used to deduce ratio between estradiol and testosterone ratio which is considered as an indicator for aromatase enzyme activity, throughout the period in which sponges were kept in vagina testosterone accumulate at expense of decreased estradiol resulting in decreased estrogen testosterone ratio indicating decreased aromatase activity, however after sponge removal estrogen testosterone ratio were increased indicating normal aromatase activity (Fig. 6). Aromatase activity showed slight increase one day following sponge insertion then started to decline till reached its minimal activity one day after sponge removal. As a result of removal of inhibitory effect, in coordination with new follicular wave emergence which began 36 hours after sponge removal preceded by increased activity of testosterone reaching peak activity 12 hours before ovulation.

\section{Biochemical parameters}

Biochemical profile including total proteins concentration, blood glucose concentration, total cholesterol concentration, triglycerides concentrations, HDL concentration, LDL concentrations were shown in Fig. (7) and there was no significant changes neither before sponge insertion nor during experiment.
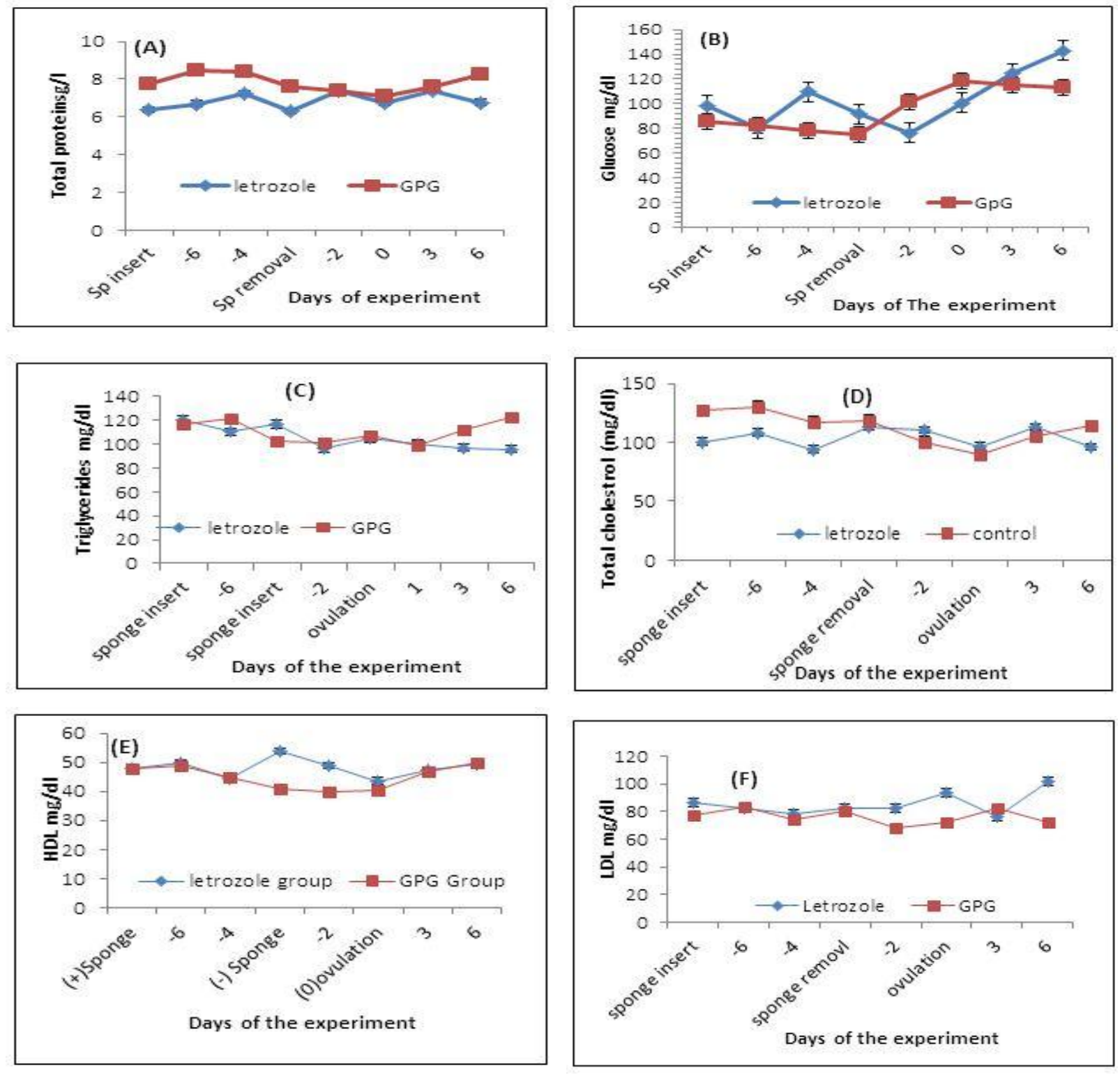

Fig.7: Concentrations of total proteins (A),Blood glucose (B), Triglycerides (C),Total cholesterol (D), High density lipoprotein (HDL) (E), and Low Denisty lipoprotein (F).From 8 days before to 6 days after the ovulation. In ewes that treated by aromatase inhibitor (Letrozole Group), And ewes that treated by ovisynch protocol (GPG Group).No significant Difference between groups $(\mathrm{P}<0.05)$. 


\section{DISCUSSION}

Just from two decades, non-steroidal aromatase inhibitors were used for induction of ovulation ( Mitwally and Casper, 2001, 2002; Navarro et al., 2008; Mitwally et al 2008). The results obtained from clinical observations of species other than ruminants has inspired many scientists to apply this substance on animals testing its effect on ovarian function and synchronicity of estrus (Rogan et al., 2011; Yapura $e t$ al., 2016.,2018).

The intra vaginal route of administration is profitable for reducing animal handling and distress resulting from daily administration attributed to other route of administration. Moreover, continuous daily dose of drug acting directly on ovaries (cunnighm, Elliot,Ginther, 2010). The two days half-life of letrozole after single administration it still about four days in circulation (Miwally, 2005) thus extended estradiol suppression during ovulatory wave were obtained through use of intravaginal sponge containing $7.5 \mathrm{mg}$ letrozole kept for five days.

As observed in this study, letrozole treatment didn't significantly affect number of small and medium sized follicles and the same were observed with the large follicles. This may be attributed to that letrozole exerts its action through inhibition of aromatization system in wall of follicles which is yet ill developed in small and medium follicles, but well developed in large follicles throughout its inhibition preovulatory $\mathrm{LH}$ surge is delayed allowed for further growth for more follicles and increase in size; As a result number of follicles attaining ovulatory size were significantly increased in letrozole group compared with GPG group. Diameter of ovulatory follicles were increased for letrozole treated group over GPG. group and this were the same result observed in cattle by yapura (Yapura et al., 2018); Thus estradiol withdrawal was associated with prolonged dominance of ovarian follicles which produced by elevated LH secretion from anterior pituitary gland resulting in increased period of FSH suppression which hinders the emergence of a new follicular wave.

In contrast to women, estrogen concentration was increased 24 hours after letrozole treatment. This was explained in rats by increased gonadotropin secretion after letrozole treatment(Sinha et al., 1998). The lower preovulatory estradiol concentration favorable for early implantation and embryonic development(Bayar et al, 2006) as lowering of estradiol concentration before implantation is more favorable for implantation and early embryo development events (Simón et al, 1995).
The larger diameter of ovulatory follicles observed in letrozole treated group may be attributed to increased sensitivity of growing follicles to gonadotrophic hormones as increased testosterone concentration enhancing sensitivity of follicular receptors to gonadotropins (de Castro, et al 1999). However estrogen and inhibin secreted from the dominant follicle has been associated with suppressive effect responsible for follicular selection (Ginther, 2003 ; Casper and Mitwally, 2012). Therefore transient elevation of estrogen concentration twelve hours after sponge insertion intravaginally together with inhibin result in arresting progress of follicular wave at stage of dominance showing a picture of over dominance(prolonged growth and maintenance of dominant follicles) .Twelve hours after sponge insertion, estradiol concentration decreased as a result of inhibition of E2 synthesis by an aromatase inhibitor with no adverse effect on the extant dominant follicle; rather, it indirectly enhance follicular dominance by permitting elevated pituitary LH secretion (Yapura $\boldsymbol{e t}$ al., 2012).

Elevated serum progesterone observed in 3 days old corpus lutem in letrozole group is similar to that in cattle (Yapura et al, 2011) which is attributed primarily to increased number of corpora lutea obtained from increased number of ovulatory follicles and secondly to increased number or proportion of large luteal cells(Granulosa cell origin) and small luteal cells thecal cell origin contained Within Corpora lutea (Alila, 1984).Furthermore corpora lutea formed after letrozole treatment probably have an increased luteal cells and there are an alteration in proportion of small and large luteal cells has occurred resulting in an increase in progesterone producing capacity of CL. (Rigoglioo et al, 2013).

Measured metabolic parameters before the experiment did not change between letrozole and $\mathrm{GpG}$ group. This is a clue that these animals were normal. Moreover, there were no any significant change throughout the sponges kept intravaginally indicating that five days letrozole treatment in this experiment did not show any unwanted changes on animal health preventing it from being furtherly used for synchronization of estrus in ewes. Although earlier reports (Wasan et al., 2005) indicated an alteration in lipid metabolism with long term use of letrozole if compared with short term use in the present study.

Based on concept that aromatase activity is positively correlated with estrogen concentration and estrogen testosterone ratio as stated by Cason and Ladly (Tsonis and Carson, 1984), Aromatase activity showed slight increase one day following sponge insertion then started to decline till reached its minimal activity one day after sponge removal. As a result of removal of inhibitory effect, in coordination with new 
follicular wave emergence which begin thirty six hours after sponge removal preceded by increased activity of testosterone reaching Peak activity twelve hours before ovulation. This observation is coinciding with the results obtained in cattle by (Yapura et al, 2016).

Variation in onset of estrus is minimized between members of letrozole group in which differences in aromatase activity were recorded is a strong indicator for the the effect of letrozole on ovarian function which is brought up by its inhibitory effect on follicular dynamics ( Mitwally and Casper, 2001) along the period of presence of sponge on vagina. Duration of estrus in letrozole group is nearly of equal values attributed to the synchronous oncet of estrus in all members of treatment group (Yapura $\boldsymbol{e t}$ al., 2016) which favoring proper timing for artificial insemination after sponge removal and GPG injection, As more accurate oncet and durations of estrus in synchronization protocols is useful as it decrease aids for estrus detection.

\section{CONCLUSIONS}

We conclude that the use of letrozole for estrus synchronization in cyclic ewes could decrease the variation in oncet of estrus which is useful specially when timed insemination protocols are implicated. Moreover, it can increase the number of ovulatory follicles which is favorable for increased twining and therefore a profitable synchrony of ovulation over GPG protocol would be obtained. Additional studies are needed on Large numbers of ewe flocks to elucidate the impact of estradiol depraviation on fertility and embryo survival.

\section{Declaration of Competing interest}

On behalf of all authors, I hereby declare that no conflict of interest may interfere with the publication of the manuscript.

\section{REFERENCES}

ALILA. HW, 1984. Origin of different cell types in the bovine corpus luteum as characterized by specific monoclonal antibodies. Biol. Reprod. 31, 1015-1025.

ANDERSSON, A., AND SKAKKEBAEK, N., 1999. Exposure to exogenous estrogens in food: possible impact on human development and health. Eur. J. Endocrinol. 140, 477-485.

BAYAR U, BASARAN M, KIRAN S, COSKUN A, GS, 2006. Use of an aromatase inhibitor in patients with polycystic ovary syndrome: a prospective randomized trial. Fertil Steril 86, 1447-1451.

CASPER, RF, MITWALLY, MFM, 2012. A historical perspective of aromatase inhibitors for ovulation induction. Fertility and Sterility 98, 1352-1355. https://doi.org/10.1016/J.FERTNSTERT.2012.10.008

CUNNIGHM, F, ELLIOT, G., GINTHER, O, J., 2010. Drug delivery system in domestic animal species. Comparative and veterinary pharmacology 199, 79.
DAXENBERGER, A., IBARRETA, D., AND MEYER, HHD, 2001. Possible health impact of animal estrogens in food. Hum. Reprod. Update 7, 340-355. https://doi.org/10.1093/HUMUPD/7.3.340

DE CASTRO, T., RUbianeS, E., MENCHACA, A., RIVERO, A., 1999. Ovarian dynamics, serum estradiol and progesterone concentrations during the interovulatory interval in goats. Theriogenology 52, 399-411.

GINTHER，OJ， BEG.F，X. DONADEU.，B， 2003. Mechanism of follicle deviation in monovular farm species. Anim Reprod Sci 78, 239-257.

GINTHER, PR, 1984. Ultrasonography of bovine ovary. Theriogenology 21, 495-504.

GOOD WINE, E., 2017. Sheep: Reproductive Management, in Husbendary of Dairy Animals. pp. 889-893. https://doi.org/10.1016/B978-0-08-1005965.21239-0

GOSS PE, AND STRASSER K. 2001. Aromatase inhibitors in the treatment and prevention of breast cancer. J Clin Oncol .19:8;81-94.

KULAKSIZ. R, UCAR O, D., 2013. Effects of FGA sponge and Ovsynch based protocols on reproductive performance of fat-tailed ewes during the breeding season. Kafkas Univ Vet Fak Derg 19(4), 29-33.

LENG, RA, 1990. Factors affecting the utilization of ' poorquality ' forages by ruminants, particularly under tropical conditions. Nutrition Research Reviews 3, 277-303.

MARTIN, P., 2016. Cost of production. Australian beef cattle and sheep producers. Abare's research report,.Canberra16.13.http://www.agriculture.gov.au/a bares/publications.

MITWALLY, M. F, AND CASPER, RF, 2002. Aromatase inhibition for ovarian stimulation: future avenues for infertility management. Curr. Opin. Obstet. Gynecol. 14, 255-263. https://doi.org/10.1097/00001703200206000- 00003

MITWALly, M. F., SAID, T., GALAL, A., CHAN, S., COHEN, M., CASPER, R. F., AND MAGARELLI, PC, 2008. Letrozole step-up protocol: a successful superovulation protocol. Official. Fertil. Steril. 89, S23-S24. https://doi.org/10.1016/J.FERTN STERT

MITWALLY, MF.., CASPER, RF, 2001. Use of an aromatase inhibitor for induction of ovulation in patients with an inadequate response to clomiphene citrate. Fertility and Sterility 75, 305-309. https://doi.org/10.1016/S0015-0282(00)01705-2

MIWALLY, MFM CASPER. R.., 2005. Single-dose administration of an aromatase inhibitor for ovarian stimulation. Fertility and Sterility 83, 229-231.

NAVARRO, E., NEYRO, L., REQUENA, A., HERRERO, J., SALVADOR, C., TUR, R., CALLEJO, J., CHECA, M.A, ESPINO, J.J., 2008. Use of letrozole in assisted reproduction: a systematic review and meta-analysis 14, 571-582.

OFFICIAL JOURNAL OFTHE EUROPEAN UNION (2003). Directive 2003/74/EC of the European Parliament and of the Council on 22 September 2003 amend- ing Council Directive 96/22/EC concerning the prohibition on the use in stock farming of certain substances having a hormonal or thyristatic action and of beta-agonist. pp. 17-21. (Publications Office 
of the European Union: Brussels.)

REQUENA A, HERRERO J, LANDERAS J, NAVARRO E, NEYRO JL, SALVADOR C, ET.AL.2008. Use of letrozole in assisted reproduction: a systematic review and meta-analysis. Hum Reprod Update, 14:5.71-82.

RIGOGLIO.N.N, FATIMA.L.A, HANNASAKA. JY, PINTO.G. L, MACHADO. A. S. Et al., 2013. Equine chorionic gonadotrophin alters luteal cells morphological features related to progesterone synthesis. Theriogenology 79, 673-679.

ROGAN, D., YAPURA, MJ, MAPLETOFT, RJ, PIERSON, RA, SINGH, J., ADAMS, GP, 2011. Effects of vehicle and route of administration of letrozole on ovarian function in cattle. Reproduction, Fertility and Development.23(1).190-190. https://doi.org/10.1071/rdv23n1ab176

SIMÓN CF, VALBUENA. D, REMOHÍ. J, P, 1995. Clinical evidence for a detrimental effect on uterine receptivity of high serum estradiol concentrations in high and normal responder patients. Hum Reprod 10, 2432-2437.

SINHA, S., KASETA, J., SANTNER, SJ, DEMERS, LM, BREMMER, WJ, SANTEN, RJ, 1998. Effect of CGS 20267 on ovarian aromatase and gonadotropin levels 45-51.

SIMPSON ER, CLYNE C, RUBIN G, BOON WC, ROBERTSON K, BRITT K, ET AL. 2002. Aromatase:a brief overview. Annu Rev Physiol 64:93-127.

TIETZ, N. W. E., 1995. Clinical guide to laboratory tests, 3rd ed. W.B.saunders,co., Philadelphia, USA.

TSONIS, C.G., CARSON, R.S., 1984. estradiol and testosterone Concentrations, and diameter and atresia of individual ovine follicles. Reprod Fert 72, 153-63.

VANSELOW J, FÜRBASS R, ZSOLNAI A, KALBE C, SAID HM, SCHWERIN M. 2001. Expression of the aromatase cytochrome P450 encoding gene in cattle and sheep.J Steroid Biochem Mol Biol 79:279-88.

VERPOEST WMJA, KOLIBIANAKIS E, PAPANIKOLAOU E, SMITZ J, VAN STEIRTEGHEM A, DEVROEY P., 2006. Aromatase inhibitors in ovarian stimulation for IVF/ICSI: a pilot study. Reprod Biomed Online 13:166-72.

WASAN, KM, GOSS, PE, PRITCHARD, PH, SHEPHERD, L., PALMER, MJ, LIU, S., TU, D., INGLE, JN, HEATH, M., DEANGELIS, D., PEREZ, EA, 2005. The influence of letrozole on serum lipid concentrations in postmenopausal women with primary breast cancer who have completed 5 years of adjuvant tamoxifen ( NCIC CTG MA . 17L ) 707-715. https://doi.org/10.1093/annonc/mdi158.

YAPURA, M.J.2012. Effects of a non-steroidal aromatase inhibitor on ovarian function in cattle. Reproduction, Fertility and Development 24, 631-640. https://doi.org/http://dx.doi.org/10.1071/RD11239

YAPURA, MJ, MAPLETOFT, RJ, PIERSON, RA, SINGH, J., ADAMS, GP, 2016. Synchronization of ovulation in cattle with an aromatase inhibitor-based protocol. Theriogenology 85, 1382-1389. https://doi.org/10.1016/j.theriogenology.2015.12.012

YAPURA, MJ, ZWIEFELHOFER, EM, PIERSON, RA, ADAMS, GP, 2018. Aromatase inhibitors: A new approach for controlling ovarian function in cattle. Theriogenology 112, 18-25.

https://doi.org/10.1016/J.Theriogenology.2017.08.025

YAPURA, MJ, ZWIEFELHOFER, EM, PIERSON, RA, ADAMS, GP, 2017. Aromatase inhibitors : A new approach for controlling ovarian function in cattle. Theriogenology 1-8. https://doi.org/10.1016/j. theriogenology.2017.08.025

YAPURA. M.J, MAPLETOFT .R.J, SINGH. J, PIERSON. R, NAILE. J, GIESY. JP, ET AL., 2011. Effects of a non- steroidal aromatase inhibitor on ovarian function in cattle. Reprod Fert Develop. 24, 1-40.
How to cite this article:

Abdel Dayem M. A., Hassan M. , Fadel M., and Senosy W.2020. Effect of A Non-Steroidal Aromatase Inhibitor on Ovarian Function and Synchronicity of Estrus in Ewes at Subtropics.Journal of Applied Veterinary Sciences, 5(4): 1 - 9.

HTTPS://DX.DOI.ORG/10.21608/JAVS.2020.117991 